\title{
Silage Quality of Napier Grass (Pennisetum purpureum Schum.) Ensiled with Rice Bran
}

\author{
Hiro-omi YOKOTA and Mitsuaki OHSHIMA \\ The Farm, School of Agricultural Science, Nagoya University, \\ Togo-cho, Aichi-ken 470-01, Japan
}

(Received October 11, 1996)

\begin{abstract}
The quality of napier grass (Pennisetum purpureum Schum.) silage ensiled with $15 \%$ untreated (URB) or defatted rice bran (DRB) and with $4 \%$ molasses in fresh matter basis in $900 \mathrm{ml}$ bottle silos was studied. Two experiments were done with different harvests season of the grass. The silos were kept for 6 months at room temperature and opened at time intervals. Silages of the 1 st experiment (dry matter content was $19.7 \%$ ) ensiled with URB showed higher pH values and ammonia content, and lower lactic acid content. Silages ensiled with DRB, however, contained enough amount of lactic acid to lower $\mathrm{pH}$ value. The quality of silages of the 2 nd experiment (dry matter content was $13.4 \%$ ) with URB or DRB was good, although ammonia content of URB supplemented silage slightly increased with time. So, to increase the dry matter with higher quality of napier grass silage, DRB was a better additive than URB.
\end{abstract}

Anim. Sci. Technol. (Jpn.) 68 (3) : 305-309, 1997

Key words : Napier grass, Silage, Additives, Rice bran, Fermentation Quality

Quality of napier grass (Pennisetum purpureum Schum.) silage was good even at low dry matter (DM) content, when the grass was ensiled with molasses ${ }^{8)}$. Yokota et al. ${ }^{9)}$, however, showed that napiergrass (DM content was $11.6 \%)$ ensiled in a plastic bag silo of $15 \mathrm{~kg}$ capacity yielded some effluent, but not the DM containing $17.0 \%$. Using Bastiman's equation ${ }^{2)}$ the silage effluent was calculated to be $27.5 \%$ of the fresh weight, when the grass contained less than $16.5 \%$ DM. Addition of $15 \%$ wheat-mill-run to fresh napier grass to increase the DM of silage material diminished the effluent, but the addition slightly decreased the lactic acid, and increased the ammonia and butyric acid contents ${ }^{9)}$.

Napier grass grows in tropical and subtropical areas, where rice plant is cultivated and lots of rice bran ( $\mathrm{RB}$ ) is produced. $\mathrm{RB}$ is ordinarily used as a feedstuff of ruminants with forages. We can also use RB as absorbent of moisture in grasses during ensiling, and it is suggested that defatted $R B(D R B$ ) is better than untreated $R B$ (URB) as absorbent. In this experiment, napier grass of low DM was ensiled with URB or DRB to increase the DM content, and fermentation quality was compared between silages ensiled with DRB and URB. And time course of the silage qualities $w$ as investigated during the 6 months storage period.

コメヌカを添加して調製したネビアグラスサイレージの品質 : 横田浩臣・大島光昭（名古屋大学農学部附属農場， 愛知県東郷町 470-01) 


\section{Materials and Methods}

\section{Herbage :}

Napier grass (Merkeron) was cultivated at the farm of Nagoya University, Aichi, Japan. In the 1st experiment, second growth of napier grass was hand-harvested on October 7, 1992. The grass was immediately chopped into $9 \mathrm{~mm}$ long. For the control silage, $500 \mathrm{~g}$ of the grass was mixed with $20 \mathrm{~g}$ of molasses and ensiled into $900 \mathrm{ml}$ of the bottle silo with a fermentation trap on the top. For RB supplementary silages, $400 \mathrm{~g}$ of the grass mixed with $16 \mathrm{~g}$ of molasses and $60 \mathrm{~g}$ of URB or DRB was ensiled similar to the control. All silos were kept at room temperature in a dark room, and opened at 1 week, 1 month, 3 months and 6 months after ensiling. Eight bottles were ensiled for each treatment and 2 bottles from a group were opened at time intervals. In the 2nd experiment, first growth of napier grass was harvested on July 23, 1993. The same experimental design was used following that of the 1st experiment. The chemical compositions of napier grass and RBs before ensiling are given in Table 1.

\section{Analysis :}

Crude protein content of the grasses and RBs was analysed by the Kjeldahl method. Crude fat content was calculated from ether extract fraction. Water soluble carbohydrate (WSC) content and buffering capacity of the napier grass were determined using freeze-dried sample by the Somogii-Nelson method after extracting with $80 \%$ ethyl alcohol and by the method of Plane and McDonald ${ }^{7}$, respectively. Silage quality was determined on cold water extract $^{6)}$. Total nitrogen of silages was measured on fresh materials.

\section{Results and Discussion}

The dry matter content of the original grasses was affected by the harvest season. The first cut grass contained more WSC than the second growth. McDonald ${ }^{5)}$ described that Italian ryegrass (Lolium multiflorum Lam.) have the highest WSC content having 18.1\% $\mathrm{DM}$, and orchard grass (Dactylis glomerata L.) the lowest having $7.9 \%$ in the common temperate grass. In the present experiment napier grass contained 4.1 or $4.5 \%$ WSC, which is comparable to the report of Kim and Uchida ${ }^{3)}$ on Rhodes grass (Chloris gayana Kunth). Buffering capacity of the napier grass in the present experiment was higher than that in the previous report ${ }^{11}$. However, these values were lower than those of Italian ryegrass (Lolium multiflorum Lam.) and alfalfa (Medicago sativa L. ${ }^{5)}$. Different brans were used in experiments 1 and 2 , and the crude protein content was more than $15 \%$ in all the brans. Untreated rice brans and DRBs contained more than $20 \%$ and less than $2 \%$ crude fat, respectively.

In the present experiment, WSC concentration was enough for silage fermentation, because $4 \%$ of molasses was supplemented to the fresh grass at the time of ensiling. Therefore, the difference of silage qualities between the 1st and 2nd experiments was attributed to the maturity stages accompanied by different moisture content of the grass which was higher in experiment 2 than in experiment 1. The silage supplemented with URB (URB silage) in the 1st experiment was much inferior to the other silages with high $\mathrm{pH}$ values, and low and gradually decreasing lactic acid content, and increasing ammonia and total volatile fatty acid (VFA) content. The increase in VFA was the reflection of butyric and propionic acids. While in the other silages, the high lactic acid content and $\mathrm{pH}$ value lower than 4 was observed at 1 month after ensiling. Control and DRB supplemented silages in the 1st experiment also showed a slight increase in butyric acid with time and a little higher $\mathrm{pH}$ value than the silages in the 2 nd experiment.

After 6 months storage, URB silage showed higher $\mathrm{pH}$ value, ammonia and VFA contents, and a lower lactic acid concentration in the 1st 
Napier Grass Silage with Rice Bran

Table 1. Chemical compositions of napier grass and rice brans

\begin{tabular}{|c|c|c|c|c|c|c|c|}
\hline & & & \multirow{2}{*}{ Dry matter } & Crude protein & Crude fat & $\mathrm{WSC}^{1)}$ & \multirow{2}{*}{$\begin{array}{l}\text { Buffering } \\
\text { capacity }\end{array}$} \\
\hline & & & & \multicolumn{3}{|c|}{$(\% \mathrm{DM})$} & \\
\hline \multirow[t]{2}{*}{ Napier grass } & lst exp. & & 19. 74 & 7.77 & $n d^{3)}$ & 4.11 & 284 \\
\hline & 2nd exp. & & 13. 42 & 8.58 & nd & 4.53 & 337 \\
\hline \multirow[t]{4}{*}{ Rice bran } & raw & 1st exp. & 89.45 & 15. 38 & 20.56 & nd & nd \\
\hline & & 2nd exp. & 86.85 & 15.35 & 21.44 & nd & nd \\
\hline & defatted & Ist exp. & 87. 14 & 21.48 & 0.99 & nd & nd \\
\hline & & 2nd exp. & 86.06 & 20.63 & 1.82 & nd & nd \\
\hline
\end{tabular}

1) Water soluble carbohydrate.

2) Mole equivalent of $\mathrm{NaOH}$ required to change the $\mathrm{pH}$ from 4 to 6 per $\mathrm{kg}$ napier grass.

3) Not determind.

Table 2. Dry matter contents $(\%)$ of napier grass silages ensiled with or without raw or defatted rice brans

\begin{tabular}{lccc}
\hline \hline & $\begin{array}{c}\text { No } \\
\text { supplement }\end{array}$ & $\begin{array}{c}\text { Raw rice } \\
\text { bran }\end{array}$ & $\begin{array}{c}\text { Defatted } \\
\text { rice bran }\end{array}$ \\
\hline 1st experiment & 21.56 & 30.62 & 29.52 \\
2nd experiment & 15.57 & 25.53 & 24.40 \\
\hline
\end{tabular}

The silages were ensiled for 7 days.

experiment. In the 2nd experiment, however, supplementation of RBs hardly affected the quality of silages, except the lactic acid content which was slightly low in URB silage. Values of $\mathrm{pH}$, lactic acid and butyric acid contents in the 1st experiment were generally higher than those of the 2nd experiment. The lactic acid contents in all the silages in the 2nd experiment were more than $10 \%$ of the DM at 1 month after ensiling, but that in URB silage was $1.9 \%$ of the DM at 1 week after ensiling, and decreased with time of storage.

Yokota et al. ${ }^{10)}$ reported that direct cut and wilted napier grass ensiled without molasses showed a lactic acid type fermentation. In the present experiment all the silages were ensiled with molasses and showed a lactic acid type fermentation except the silage ensiled with URB in the 1st experiment, which produced high levels of total VFA and ammonia during ensilage when moisture content of silage was about $70 \%$. Lawilai et $a l .{ }^{4)}$ reported that $\mathrm{pH}$ values of the wilted water hyacinth (Eichhornia crassipes (Mart.) Solms) ensiled with graded levels of RB, decreased with increasing levels of additive, and concluded that 15\% RB was enough to depress the concentration of ammonia, although the $\mathrm{pH}$ value was more than 4.8 . In their study, wheat bran added water hyacinth silage fermented much better than RB added one, judging from the organic acid content which was produced during the ensilage process. In the present experiment, the lactic acid contents in silages ensiled with URB in the 1st experiment was lower than those in the 2nd experiment. These difference might be due to the quality of URB, although we used commercial URBs as fresh as possible. The URB used in the 1st experiment might contain oxidized fat which inhibited lactic acid fermentation in the silage.

Napier grass ensiled with DRB in a polyethylene bag of $15 \mathrm{~kg}$ capacity for 9 months showed higher total VFA and ammonia contents than that of molasses supplementation with and without DRB (Yokota et al., unpublished data). The difference between the previous experiment and the present one may be due to the scale of silo, duration of storage and moisture content of the grass. Generally speaking, it is well known that URB is high in unsaturated fatty acids and easily oxidized during storage, especially in a hot season. As 

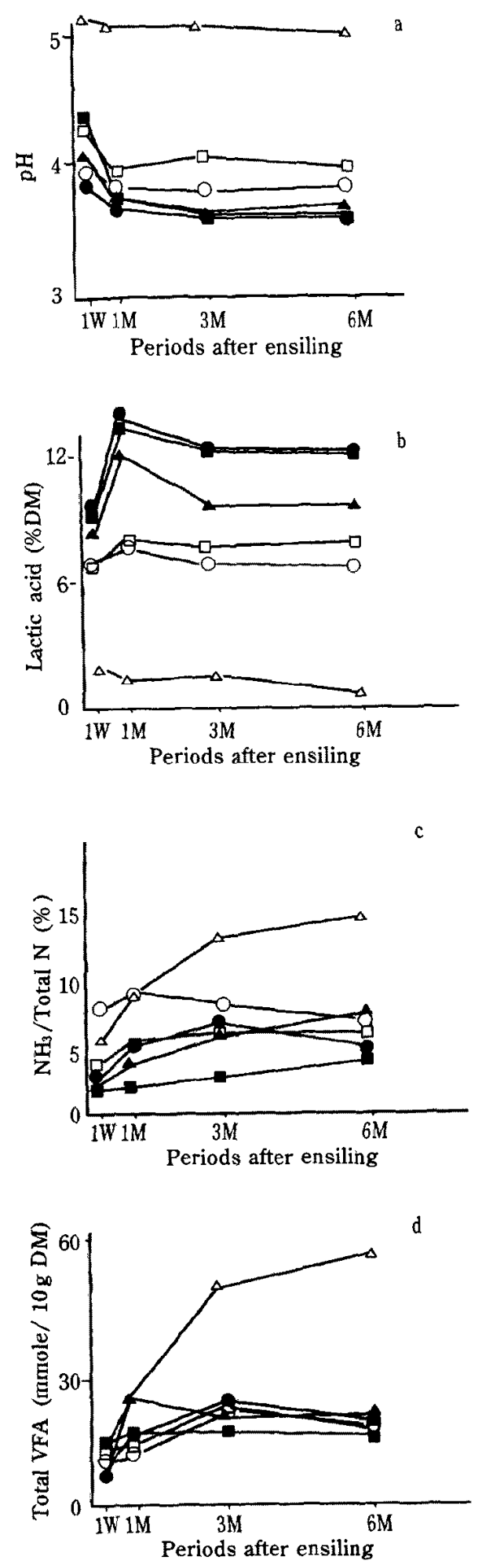
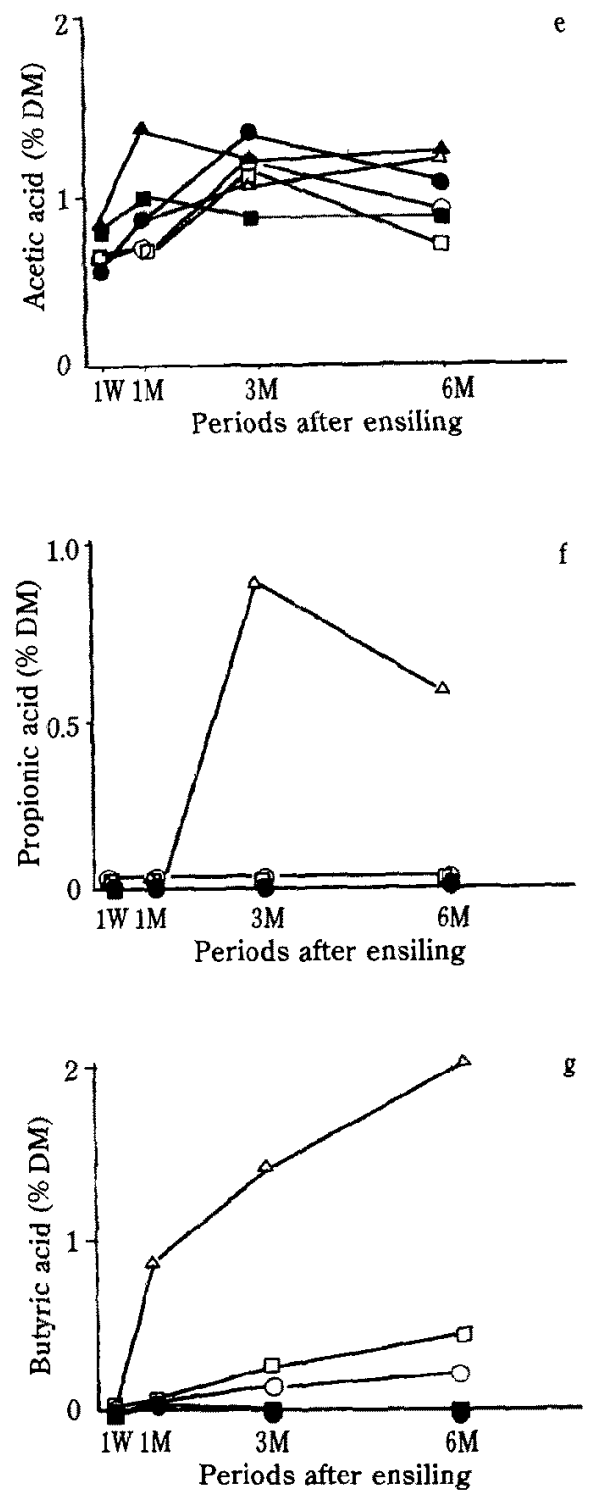

Fig. 1. Time course changes of $\mathrm{pH}$ value (a), lactic acid (b), ammonia nitrogen/total nitrogen (c), total VFA content (d), acetic acid content (e), propionic acid content (f) and butyric acid content $(g)$ in napier grass (Pennisetum purpureum Schum.) silages. In the 1st experiment, $\bigcirc$ showed no supplemented silage, $\square$ defatted rice bran supplemented silage, and $\triangle$ untreated rice bran supplemented silage. In the 2nd experiment each sign was black respectively. 
the oxidized fat is harmful for animals, attention should be given in the use of URB as feedstuff.

In conclusion $\mathrm{DRB}$ is a better silage additive than URB for napier grass, from the view point of the fermentation quality of silage and the nutritional quality of the bran.

\section{Acknowledgements}

The authors wish to thank Messrs. N. Inagaki, M. Tsuge and M. Maesaka for cultivation and ensilage of napier grass.

\section{References}

1) Barnett AJG. The calorimetric determination of lactic acid in silage. Biochem. J., 49 : 527-529. 1951.

2) Bastiman B. Factors affecting silage effuent production. Expl. Husb., 31 : 40-46. 1976.

3) Kim K-H, Uchida S. Comparative studies of ensiling characteristics between temperate and tropical species. J. Japan. Grassl. Sci., 36 : 292-299. 1990.

4) Lowilai P, Kabata K, Okamoto C, Kikuchi M. Effects of rice bran and wheat bran on fermentation quality and chemical composition of water hyacinth silage. J. Japan. Grassl. Sci., $40: 271-277.1994$.
5) McDonald P. The biochemistry of silage. 20-31. John Wiley and Sons. Chichester. 1981.

6) Ohshima M, Miyase K, Nishino N, Yokota H. Ruminal acid concentrations of goats fed hays and silages prepared from Italian ryegrass and its pressed cake. Asian-Australasian J. Anim. Sci., 4: 59-65. 1991.

7) Plane $\mathrm{MJ}, \mathrm{McD}$ onald $\mathrm{P}$. The buffering constituents of herbage and of silage. J. Sci. Fd Agric., $17: 264-268.1966$.

8) Yokota H, Okajima T, Ohshima M. Effect of environmental temperature and addition of molasses on the quality of napier grass (Pennisetum purpureum Schum.) silage. AsianAustralasian J. Anim. Sci., 4: 377-382. 1991.

9) Yokota H, Okajima T, Ohshima M. The effect of wheat-mill run addition to napier grass (Pennisetum purpureum Schum.) at ensiling on its nutritive value for goats. J. Japan. Grassl. Sci., $40:$ 420-428. 1995.

10) Yokota H, Ohshima M, Kim JH, Okajima T. Lactic acid production in napier grass (Pennisetum purpureum Schum.) silage. Grassland Science, $41: 207-211.1995$.

11) Yokota H, Ohshima M, Choi I, Tamada J Effect of wilting on the silage quality of napier grass (Pennisetum purpureum Schum.) Proceedings of the 8th AAAP Animal Science Congress, 2: 888-889. 1996. 